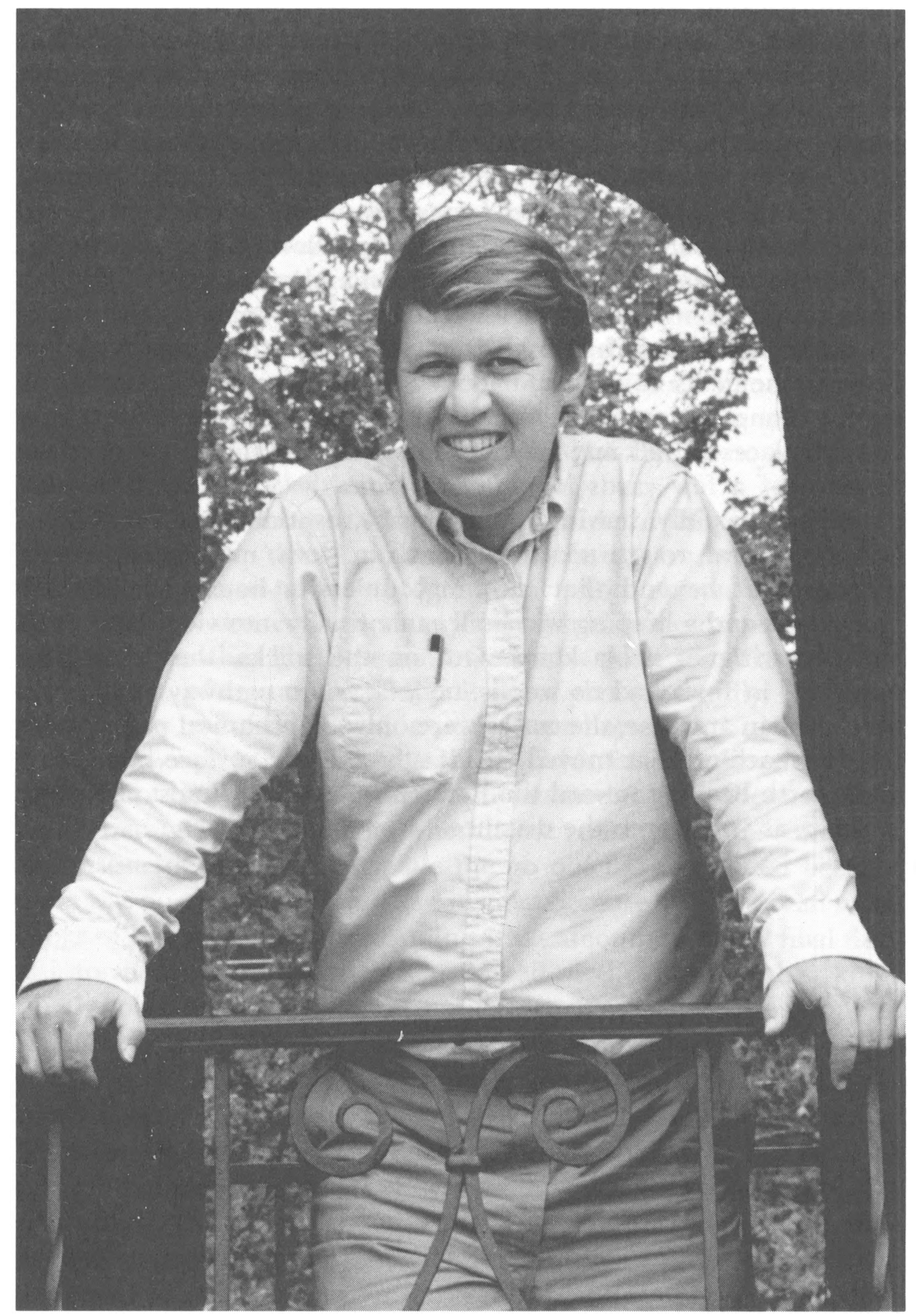

Christopher Roy. Photograph by Anne Lattimore. 


\title{
INTERVIEW WITH CHRISTOPHER ROY
}

\author{
Emily Braverman
}

Christopher D. Roy, Associate Professor of Art History, has taught at The University of Iowa since 1978. Although his interests include Oceanic, pre-Columbian, and Native American Indian art, his major area of research is African art and culture. He has taken frequent trips to Africa, beginning in 1970 as a Peace Corps volunteer in Upper Volta (now Burkina Faso), again to Burkina Faso in 1976-77 as a Fullbright Scholar to do dissertation research, and returning in 1983, 1984, and 1985 to continue his research on a University of Iowa Faculty Scholarship. Professor Roy also serves as Adjunct Curator of Tribal Arts at The University of Iowa Museum of Art, and has written three exhibition catalogs for the museum: African Sculpture: The Stanley Collection (1979); African Art from Iowa Private Collections (1981); and Art and Life in Africa: Selections from the Stanley Collection (1985). Professor Roy's numerous publications include journal articles, reviews, and a recently released video entitled Art and Death in Africa, made from films taken while doing research in West Africa. His most recent book, The Art of the Upper Volta Rivers, is the first scholarly publication on the traditional art of Burkina Faso, one of the richest art-producing areas of Africa.

As an undergraduate you were interested in Northern Renaissance art. When did you encounter African art and what drew you to it?

I've been interested in art and art history ever since I was a child when I used to go to museums in New York on the subway by myself. In college I began studying art history. Then, between college and high school I hitch-hiked across North Africa into Egypt. So I'd gotten some interest in Africa there because I'd gone to a Bedouin Festival in a town called El-Oued in Southern Algeria, and there were a lot of Nigerians there, and I was interested in where they came from. I 
thought it was kind of an exotic experience. So I studied art history in college, and then, because I and my father and mother had been fans of the Kennedys, especially Bobby Kennedy, and the Peace Corps, and my headmaster in high school had been the first director of the Peace Corps in Nigeria, I went into the Peace Corps in 1970, right out of college. I went to Burkina Faso on the African Arts Project. I was serving as Acting Director of the National Arts Center of Ouagadougou from 1970-72. So through my work in Burkina Faso combined with my background in Western art history in college and my experience in European museums and North Africa, I got interested in African art, and that led to graduate school.

Had you taken any courses in African art specifically?

Never, not until I got to graduate school.

Tell me more about the Arts Project in the Peace Corps. What were you doing there?

A Frenchman named Lauchez had convinced the Ministry of Education of Ouagadougou that they should create an open-air museum like the one that still exists in Niamey Niger, in which craftsmen were brought in to demonstrate their work for tourists, and tourists could come and see them working and buy their crafts. He needed support, so he asked the Peace Corps for five Peace Corps volunteers who would each be in charge of a section such as pottery, weaving, sculpture, blacksmithing, and so on. Five Peace Corps volunteers with college backgrounds in studio art were hired, and I was one. I was the person who was supposed to be in charge of the pottery section. But just before we arrived, Lauchez, the Frenchman, called the Minister of Education a dirty name and was given twenty-four hours to get out of the country. Rather than pack up the whole program, they made me the Director because I was the only one of the five Peace Corps volunteers who already spoke fluent French. So for two years I ran that project.

You weren't going out collecting pieces that were used?

No, I went out, but not collecting. I went out collecting peoplefinding craftsmen who were working, and who were willing to come to work in Ouagadougou for a salary. We paid them a regular salary and sold their work through the Arts Center in Ouagadougou, the capital city. So I explored and travelled around the country by car. The 
Frenchman had asked the French Embassy for an air-conditioned Peugot station wagon, and that was delivered just after I became Director. So I was the only Peace Corps volunteer in the world with an air-conditioned car, new.

What kind of objects did you find when you got there?

At that time, before I ever studied African art, I wasn't interested in the sculpture. Because of my job I was interested in crafts such as weaving, pottery, and brass-casting. So that was the kind of thing I looked for, and that's what I found. There was a lot of sculpture that was being sold by antiquities dealers, but I didn't feel I knew enough about it to get very interested in it. And it wasn't until after I had gotten formal education at Indiana as a graduate student that I paid much attention to the sculpture, personally. After I got out of the Peace Corps, I went to an exhibition at the Museum of Modern Art called African Textiles and Decorative Arts that had been curated by Roy Sieber. I realized this was exactly what I had been studying at Burkina Faso-the same kinds of textiles and wrappings and furniture and things like that. So I fired off an application to Indiana and ended up there for three years.

When you went back to Burkina Faso to do field work, did you study sculpture and masks?

Yes, I started graduate school in '73. Late in '75 my wife and I got Social Science Research Council Grants and Fulbright Program Grants. And in June of '76 we went to Burkina Faso for the second time to spend fourteen months in what was then called Upper Volta in a village called Yako, doing research on Mossi sculpture. African art is brilliant. It's different, it has strength, it's moving, it's great art. It tells us a lot about Africans, and it tells us a lot about ourselves.

Was your approach to the study of African arts different from your approach to the study of Western arts?

Not in the least. It was absolutely identical. My models were the models that I'd used in studying Western art history. They were Panofsky and all the other art historians. I was interested in the same kinds of things. I was interested in style, in the relationships between styles and the way styles are reflected, the influence on the artists of their contact with other people, with other artists. I guess the only way that it differed at all was that there was more emphasis on the 
meaning and the function and the performance of the objects in their traditional village. Not to say that such things are not of interest to Western art historians, but there was just a greater emphasis on that kind of thing in my work than there had been when I studied the Renaissance in Italy or Northern Europe.

Is there a conflict in the study of art between a Formalist approach and an approach that studies the cultural context of the art?

The only conflict I see is when the Formalist approach isn't done well and isn't integrated into an understanding of the art objects in a larger context. If a Formalist approach is purely descriptive and doesn't analyze or go into enough depth to make sense of the objects, then it is inadequate. But a Formalist approach can be useful too because it can make sense of relationships beyond art. As an example, the research I did for my dissertation was Formalist in that I was going around to different villages and asking them what their art looked like, showing them photographs, seeing all that I could. I was doing a comparative Formalist study, and I found out that the styles that I recognized only occurred in certain geographical areas. By comparing the styles of a particular geographical area with the style of the nearest non-Mossi neighbors, I realized that those geographical styles corresponded to the ancient populations of this particular region and to the area where ancient populations had been conquered and amalgamated into a new ethnic group. So the Formalistic study of styles led to an understanding of the historical process that had gone into the creation of the Mossi group. It made sense out of the history of the Mossi and wasn't just purely descriptive or Formalist for its own sake.

The University of Iowa Museum of Art houses the Stanley Collection, one of the largest collections of African Art in the country. What is the role of the museum? Should it simply present the objects, or should it provide information on their fuction within a cultural context?

Well, I'm a teacher, so I think the museum should use them as teaching tools. It should present material that helps people understand what the objects mean. That's the same kind of approach, though, that you see if you go to the Metropolitan Museum of Art to an exhibition of paintings by Van Gogh. You see these enormously long labels that explain what was going on, where Van Gogh lived, what was wrong with his mind. That's the same kind of didactic information that can help people make sense out of what they see in the Stanley Collection. 
There is a school of thought, though, that says there should be no labels because objects should be appreciated for their formal qualities, not their cultural contexts.

I totally disagree with that school of thought. The objects have an affecting presence. Sure, you can enjoy them by just looking at them, but ninety percent of the people who look at them aren't going to enjoy them. They're going to think that they're crude, they're bizarre, they're strange, they're exotic, they're outlandish-because they don't understand them. If you've got labels so that you know what's going on, you understand those objects.

What is the relationship between art and life in African society.

The objects that you see in the museum are tools in religious, educational, political, ancestral, and magical beliefs and practices. They are art because they are a profound expression of ideas. But at the same time they're totally utilitarian, and because they are utilitarian, you can only understand them at the most superficial level if you don't understand how they are used.

You are a scholar, you've written a book and produced a film. But as the Curator of the Stanley Collection you are also responsible for finding the best possible examples of art objects to make it a fine collection. Are there any conflicts in having that dual role?

Yes, it creates a little bit of schizophrenia because I like to think of the objects appearing in the context in which you see them in my photographs, being worn with a costume, being worn in performance, being used in the village. And if somebody collects them and puts them in a museum, they can't serve that role anymore. On the other hand, if I were a pre-Columbian art historian, I would be totally schizophrenic because there aren't any pre-Columbians around to replace what is taken out of a grave or tomb or something like that. Once it's been removed from the archeological context, it can't be replaced. In contrast, in Africa, there are plenty of artists who are still working like mad to replace objects that people in those photographs, in those villages, sell to local dealers who then sell them to a European dealer, who then sells them to an American collector. And to a great extent, the demand for the objects in the Western market creates a greater demand on the artist to produce. Therefore the artists are more active now than they might have been if there weren't such a 
demand on the market. Very few of these objects are stolen, so that's not a problem for me. These people are too sharp to let those things be stolen. When they catch people trying to steal them, they torture them. They are brutal with anybody who is silly enough to try to do a thing like that, and they're quite capable of taking care of themselves, generally speaking. But they're also very pragmatic, so if an object gets old or broken and doesn't function anymore as a tool they replace it with one that works-just as you would fix a broken tool or throw it away and get a new one. The old one can be sold for, often, quite a bit of money. There was one mask that I bought from a man who had had it carved to treat his children for eye disease and it didn't work. It was broken. It didn't function. He wanted to get rid of it. He wanted to sell it for enough money to have one carved that would work, so he asked me to buy it. So, I rationalize the fact that some of these pieces are in the museum because, at least in some cases, the people who owned them sold them, and because some of the very best pieces have been out of Africa for a long time. So, I try to be pragmatic about it, and it makes sense to try to present this material to people, to students, as an example of world culture.

\section{Do you collect for the Stanley Collection?}

No. When I'm in Africa, I never, ever collect objects for the Stanley Collection. First of all, and with very few exceptions, I never collect objects myself, for my own collection. I have a collection, but with the exception of one or two masks, my collection is just of functional objects like whistles and flutes and stools and things that I enjoy. The masks that I've collected have been sold to me by people who expressly asked me to buy them because they wanted to get rid of them for some purpose. For example, the big mask that I have on the wall was broken. It's cracked-it's not functional. So the family who owned it asked me if I would buy it. After some negotiation, I did. But, as a scholar doing research on African Art in Africa my function isn't to collect it. The Stanley Collection pieces come from European dealers and European collections, not from me.

How has the collecting of African Art in the West affected the way Africans see their own sculpture? Does it make the objects any less sacred to them?

Once an object is out of their hands, it's not sacred at all. It's no more sacred than a seventeenth-century chalice that you might see in a museum in Northern Europe. Is that a sacred Christian object, or is it a secular work of art? It's not in a church anymore. It's not being used 
during the elevation of the Host anymore. When these African Art objects are not being used in a performance, they're not attached to the costume, so they're just a wooden carving. Once people have no longer made sacrifices on them, they no longer have any kind of sacred or magical power. And so they are just looked on as carvings, wooden carvings.

What do the Africans think about people wanting to collect the objects just to hang on a wall.

They think that's a little bizarre. They don't understand that. An African friend of mine who came to visit, saw a piece that he recognized as the type that comes from his village, but it was stripped of its costume. He said, "Well, that's just the head. That's not the mask." I said, "There's at least a mask." He said, "No, that's not a mask." I was talking about a mask as something that goes over the face, but he was saying that without its costume it's not the mask, it's just the head of the mask. And the head of the mask has no importance whatsoever.

When we gain access to African Art, do the African's lose it?

I think Africans are durable, generally. Africans aren't frozen in time any more than any other culture is. Even the most resistant cultures change. But African cultures are not fragile either, for the most part. There are some exceptions like the Baule. It's markedly different from Polynesia, for instance. African cultures have survived intact up to now. I mean, the first Europeans arrived along the coast in the fifteenth century. Colonialism began at the end of the nineteenth century. A hundred years later these cultures still survive and persist. I know things'll change, but I don't think they'll disappear. In 1923 it was too early for Frobenius to write Dying Africa. It's still too early for anybody to write a book with that title.

What is the difference between the way you look at objects in Africa and the way an Anthropologist would study the same objects.

It's 180 degrees opposed. We end up with similar results, but we come at the material from opposite directions. I'm interested in objects because they are wonderful, because they have the strength to move us, to impress us. And I study the people who made them so that I can understand the objects. I study who they were influenced by, the symbolism, everything that has to go together to make sense out of the 
object. In contrast, anthropologists use the objects as tools for understanding the people. So the end result is that the object is of little value to the anthropologist. It's what the object tells about the people that's important. For me, it's the object that's important, and the people help me understand the object.

\section{Can you tell me about your most recent book?}

It's called Art of the Upper Volta Rivers, and it's supposed to come out in June. It's a survey of five or six different ethnic groups that I've studied. It's an art historical study because it makes sense out of the style relationships between lots of ethnic groups in a fairly broad geographical area. In terms of placing the art objects in their cultural context, with the exception of the Mossi, I only had time to do a survey and not to spend a year in each village. If you're doing a survey of a hundred villages, you can't spend a year in each village. Right? But it will be the only book available that deals with most of Burkina Faso. In fact, there's only one book on the art of Burkina Faso at all, and that only deals with one ethnic group. My book is the fruit of fifteen years research. It's going to be expensive. It will have three hundred fifty photographs of about two hundred fifty pieces, seventy of my black and white field photographs, and about ten color field photographs. It deals in some depth with art in context. I spend a lot of time talking about the names of objects and how they fit in and what they mean and the roles that they play in funerals and initiations and burials and market day dances and all that sort of thing, so there's a great deal of that too. But you'll see when you read it that because I was able to spend a year in a Mossi village, the section on Mossi deals with function and meaning in greater depth than I could do with the Bwa or the Bobo in whose villages I only spent a short period of time. It's being published in French and English together in the same book. So it'll appeal both to the American and French collectors. There are a lot of French people who are collectors and who are interested in Burkina Faso because it used to be a French colony.

What else would you like to talk about?

Nobody ever asks me about doing research or what life is like in Africa or what its like doing research in Africa.

What is it like?

Doing research in Africa is not like doing research at the Uffizzi. 
That's hard work too, but you can't go around the corner to get an aperitif, to get a cup of coffee when you get sleepy. You can't go home and get a hot shower. You don't have a comfortable bed to sleep in. It's really tough, and it's grueling day after day after day after day. But the rewards are the excitement of seeing living works of art and feeling your reaction to them. The hair standing up on the back of your neck the first time you see a mask performed-a mask that you've seen in nothing but photographs or films for years before. It's like nothing else that you experience. It's a lot of fun. But it is also hard work. It might seem romantic to someone who hasn't been there. But when you're there it's not romantic. When you're there, it's dirt and dust, and hard work. When you get bad food and stomach cramps, you don't feel very well. But when you come home, ten years later you remember the mask dancing and the sound of the drums. You remember lying in bed at night under the African sky listening to fruit bats and hearing the drums in the village playing while people dance-or going off to a performance at night with your tape recorder. Those are things you remember; you don't remember the stomach cramps or the dust or the heat or the bad food. That's what Africa's like.

How do people deal with the heat?

Oh, if you go to an African village at mid-day, it might as well be deserted. You don't see a single person out. Everybody's lying down in a cool room, trying to get through the hot hours of the day.

Do they work, then, into the night or do they get up extra early?

They get up at dawn, they work until eleven, then they take what's called a siesta from eleven till five. They get up at five o'clock, and that's when the real day begins, at five o'clock. They go out and work in the fields a little more, they have supper, they do a little trading, they gossip, they have a cup of coffee. They stay up until late-twelve o'clock, one o'clock. On nights when there's a full moon, African villages are incredibly noisy because everybody's walking around talking and joking and playing games and telling stories and dancing and doing all sorts of things. Because the full moon's the only thing that gives light. In Africa, you remember the moons. I mean, you pay attention to whether the moon is a quarter or a three-quarters or half or full, because if it's not, you don't have any light to see by and you fall over that $\log$ and you fall down the well. You know? So, it's important. 